УДК 338.054.23 JEL E70

Гайнанов Дамир Ахнафович д-р экон. наук, ФГБНУ Уфимский федеральный исследовательский центр Российской академии наук, г. Уфа, Российская Федерация ORCID: 0000-0002-2606-2459 e-mail:2d2@inbox.ru

\section{Атаева Айсылу}

Гарифулловна

канд. экон. наук, ФГБНУ Уфимский федеральный исследовательский центр Российской академии наук, г. Уфа, Российская Федерация

ORCID: 0000-0002-2835-0147

e-mail: ice_lu@mail.ru

\section{Gaynanov Damir}

Doctor of Economic Sciences, Ufa Federal Research Center, Russian Academy of Sciences, Ufa, Russia ORCID: 0000-0002-2606-2459 e-mail:2d2@inbox.ru

\section{Ataeva Aysylu}

Candidate of Economic Sciences, Ufa Federal Research Center, Russian Academy of Sciences, Ufa, Russia

ORCID: 0000-0002-2835-0147

e-mail: ice_lu@mail.ru
DOI 10.26425/1816-4277-2020-10-93-100

\section{ВЛИЯНИЕ ВНЕШНИХ ВОЗДЕЙСТВИЙ НА ДИНАМИКУ ОТРАСЛЕВОЙ СТРУКТУРЫ ВАЛОВОГО РЕГИОНАЛЬНОГО ПРОДУКТА}

Аннотация. Проведена оценка влияния отраслевой структуры валового регионального продукта регионов России на устойчивость региональных экономик внешним кризисам (на примере нефтяного кризиса и распространения коронавирусной инфекиии). Во-первых, на основе сопоставления трендов изменения цены на нефть и валовой региональный продукт регионов России за последние 20 лет определено, что нефтяной кризис повлияет на экономическое развитие всех регионов вне зависимости от специализачии территории. Во-вторых, установлено, что регионы, в которых высокая доля промышленности сырьевой направленности и низкая доля торговли, транспортировки, финансового сектора, являются более устойчивыми к последствиям распространения коронавирусной инфекиии. На примере Республики Башкортостан определены угрозы современной структуры экономики и социальной сферы с точки зрения устойчивости внешним кризисам, предложены направления структурной и пространственной перестройки экономики региона для повышения устойчивости региональной экономики.

Ключевые слова: антикризисное управление, валовой региональный продукт, виды экономической деятельности, коронавирусная инфекция, нефтяной кризис, регион, региональная экономика, экономическая устойчивость, экономическая специализация.

Для цитирования: Гайнанов Д.А., Атаева А.Г. Влияние внешних воздействий на динамику отраслевой структуры валового регионального продукта//Вестник университета. 2020. № 10. С. 93-100.

\section{INFLUENCE OF EXTERNAL IMPACTS ON THE DYNAMICS OF THE INDUSTRIAL STRUCTURE OF GROSS REGIONAL PRODUCT}

Abstract. The article assesses the impact of the sectoral structure of the gross regional product of the Russian regions on the sustainability of regional economies to external crises (using the oil crisis and the spread of coronavirus infection as an example). Firstly, based on a comparison of the trends in oil prices and the gross regional product of Russian regions over the past 20 years, the paper determines that the oil crisis will affect the economic development of all regions, regardless of the specialization of the territory. Secondly, the study ascertains that regions, which have a high share of the raw materials industry and a low share of trade, transportation, and the financial sector, are more resistant to the consequences of the spread of coronavirus infection. Using the example of the Republic of Bashkortostan, the authors identify threats to the modern structure of the economy and the social sphere in terms of sustainability to external crises, and propose the directions of structural and spatial restructuring of the region's economy to increase the stability of the regional economy.

Keywords: crisis management, coronavirus infection, economic specialization, economic sustainability, gross regional product, oil crisis, region, regional economy, types of economic activity.

For citation: Gaynanov D.A., Ataeva A.G. (2020) Influence of external impacts on the dynamics of the industrial structure of gross regional product. Vestnik universiteta. I. 10, pp. 93-100. DOI: 10.26425/1816-4277-2020-10-93-100

Самой актуальной темой исследований в отечественной экономической науке в 2020-2021 гг. предсказуемо будет оценка влияния распространения пандемии COVID-19 на социально-экономическое развитие регионов, в особенности, когда будут доступны первые статистические данные по отдельным экономическим и социальным показателям.

Благодарности. Исследование выполнено в рамках государственного задания УФИЦ РАН № 075-01211-20-01 на 2020 г.

Acknowledgements. The study was carried out within the framework of the state task of the Ufa Federal Research Center of the Russian Academy of Sciences No. 075-01211-20-01 for 2020.

( С Гайнанов Д.А., Атаева А.Г., 2020. Статья доступна по лицензии Creative Commons «Attribution» («Атрибуция») 4.0. всемирная (http://creativecommons.org/licenses/by/4.0/).

The Author(s), 2020. This is an open access article under the CC BY 4.0 license (http://creativecommons.org/licenses/by/4.0/). 
Предварительные оценки последствий распространении пандемии COVID-19 уже проведены крупнейшими исследовательскими центрами. Согласно прогнозам Международного валютного фонда, в связи с пандемией коронавирусной инфекции, совокупный валовой внутренний продукт (далее - ВВП) стран сократится более чем на $5 \%$. Такое снижение валовой добавленной стоимости объясняется разрушенными цепочками поставок, сокращением потребительского спроса, увеличением числа безработных, закрытием границ и ожиданием повторных вспышек вируса. Сокращение экономической активности сконцентрировано в розничной торговле и общественном питании, услугах, транспорте, культуре, спорте и туризме [10].

По исследованиям McKinsey\&Company падение ВВП в России может составить от 3,8 \% до 10 \%; Института исследований и экспертизы ВЭБ.РФ - от 2,1 \% до 5,1 \% в зависимости от режима самоизоляции в 2020 г. ВВП России снизится на 5,5 \% в 2020 г. (по сравнению с ростом на 1,2 \% в 2019 г.), а в 2021 г. он увеличится на 2,2 \%, прогнозирует Moody's [18]. Согласно пересмотренным параметрам базового сценария прогноза Банка России, ВВП в 2020 г. снизится на 4-6 \% [9].

В отечественной науке пока только начинают появляться исследования по влиянию пандемии коронавируса и нефтяного кризиса на мировую и отечественную экономику (май 2020 г.). Ряд авторов определяет, что экономическая рецессия вследствие пандемии будет обусловлена не финансовыми факторами (как это было в 2008 г.), а запретами на общение и личное потребление услуг, которые ранее обычно не были подвержены колебаниям [6; 7]. Многие авторы уверены, что пандемия станет серьезным вызовом для общественных наук, поскольку старый образ мышления часто будет бесполезен при анализе и объяснении новых ситуаций [8].

При этом нельзя забывать, что распространение пандемии наложилось на нефтяной кризис: снижение спроса на нефть и нефтепродукты из-за пандемии, неопределенность в отношении сделки ОПЕК+ и избыточное предложение нефти, - все это привело к резкому падению цены на нефть марки «Brent» $[10 ; 13 ; 17]$. Именно наложение пандемии на зависимость экономики отдельных регионов от цены на нефть повлияет на скорость выхода из кризиса. Связано это со структурой составляющих ВРП каждого региона.

Логично предположить, что регионы, валовой региональный продукт (далее - ВРП) которых находится в сильной зависимости от развития нефтяной отрасли, в большей степени пострадают от падения цены на нефть, что усилит негативные экономические последствия распространения коронавируса. Однако это не так. Сопоставив тренды изменения цены на нефть и ВРП за последние 20 лет, можно сделать выводы, что нефтяной кризис скажется на экономическом развитии всех регионов, вне зависимости от специализации территории. Для анализа мы выделили три группы регионов:

1) регионы-лидеры по добыче нефти. К ним отнесены Ханты-Мансийский автономный округ, Республика Татарстан, Ямало-Ненецкий автономный округ, Красноярский край, Сахалинская и Самарская области. В связи с отсутствием статистических данных по ВРП Ханты-Мансийского и Ямало-Ненецкого автономных округов до 2010 г., анализ проводился в целом по Тюменской области;

2) регионы-лидеры по переработке нефти. Регионы определялись, исходя из имеющихся мощностей по переработке нефти: Республика Башкортостан, Самарская, Волгоградская, Ленинградская области, Краснодарский край;

3) регионы, не связанные с нефтяной промышленностью. К таким регионам отнесены субъекты Российской Федерации, в которых суммарная доля таких видов экономической деятельности, как «добыча полезных ископаемых» и «перерабатывающая промышленность» минимальна в 2018 г.: республики Калмыкия, Дагестан, Алтай, Ингушетия и Северная Осетия - Алания.

Среднедушевой ВРП в первой группе (регионы-лидеры по добыче нефти) в 2018 г. почти в 3,0 раза превышает среднее значение во второй группе (регионы-лидеры по переработке нефти) и более чем в 6,6 раз превышает значение в третьей группе регионов, не связанных с добычей и переработкой нефти. Это отражает отраслевую специфику регионов и влияние наличия нефтедобычи и нефтепереработки в регионе на экономические результаты. Такой разрыв характерен почти для всего двадцатилетнего периода: разрыв между первой и второй группой планомерно рос от 2,1 раза (1998 г.) до 3,0 раза (2018 г.), между первой и третьей группой - колебался в значениях от 5,2 раза (2016 г.) до 7,6 раза (2005 г.).

Проведенный корреляционно-регрессионный анализ показал наличие явной зависимости между ценой на нефть и среднедушевым ВРП во всех трех группах (хотя надо отметить, что зависимость между ВРП и ценой на нефть, выраженной не в рублях, а в долларах не столь существенна). Коэффициент линейной 
корреляции Пирсона для первой группы составил 0,9634, для второй $-0,9592$, и даже для третьей $-0,9419$, что позволяет говорить о достаточно тесной связи между показателями (рис. 1).

Из рисунка 1 видно, что графики изменения цены на нефть и ВРП на душу населения в первой группе регионов схожи по траектории: пики и спады показателей совпадают во временных отрезках. Не столь явная графическая зависимость для второй и третьей групп обусловливается невысокими значениями показателей.

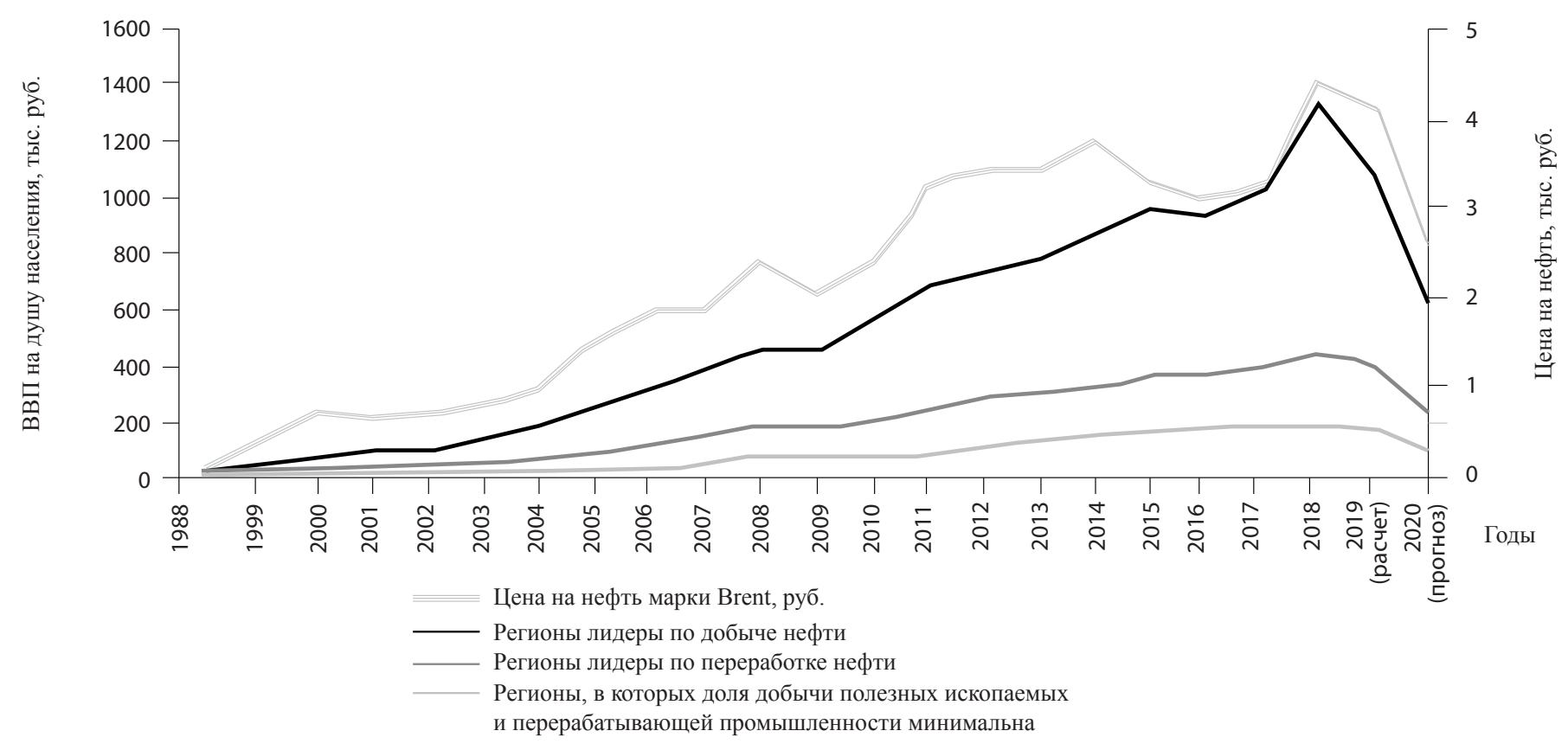

Составлено авторами по материалам исследования

Рис. 1. Динамика изменения ВРП на душу населения в отдельных регионах России в 1998-2020 гг. в текущих ценах

Наличие такой зависимости позволило построить модель линейной регрессии и рассчитать оценочное значение ВРП за 2019 г. и спрогнозировать условное изменение ВРП в 2020 г. при цене на нефть в 2019 г. и средней цены за баррель нефти на уровне 35,61 долл. США по итогам 2020 г. по прогнозам Международного валютного фонда (рис. 1). Во всех трех группах динамика спада идентична и составляет приблизительно 44-45 \% вне зависимости от типа региона. Фактические значения, конечно же, будут отличаться в зависимости от принятых мер поддержки экономики. Таким образом, нефтяной кризис повлияет на все регионы, вне зависимости от экономической специализации.

Что касается последствий коронавируса, то они напрямую зависят от экономической специализации региона. Рассмотрим структуру ВРП регионов наиболее и наименее пострадавших от коронавируса. Согласно предварительной оценке Института исследований и экспертизы ВЭБ.РФ, в меньшей степени пандемия повлияет на экономику Ненецкого, Ямало-Ненецкого, Ханты-Мансийского, Чукотского автономных округов, республик Коми, Саха (Якутия), Тыва, Северная Осетия-Алания, Карачаево-Черкессия; Астраханской, Магаданской, Сахалинской, Оренбургской областей, Камчатского края [17]. В наибольшей степени от коронавируса пострадают города федерального значения Москва и Санкт-Петербург с областями (см. рис. 2).

Рассмотрим усредненную структуру ВРП этих регионов в 2018 г. (см. рис. 3). Из рисунка 3 видно, что в регионах с наибольшим спадом ВРП в результате распространения коронавируса, высока доля обрабатывающих производств, торговли, транспортировки и хранения продукции. В наименьшей степени повлияют на ВРП последствия коронавируса для экономики регионов, специализирующихся на добыче полезных ископаемых (43,0 \% ВРП).

Конечно, нельзя сказать, что структура экономики напрямую влияет на устойчивость региона к последствиям распространения коронавируса, необходимо учитывать еще множество других факторов. Но с определенной долей условности можно сказать, что регионы, в которых высокая доля промышленности сырьевой направленности и низкая доля торговли, транспортировки, финансового сектора, являются более устойчивыми к угрозам закрытия границ, разрушения цепочек поставок, сокращения потребительского спроса, самоизоляции. 


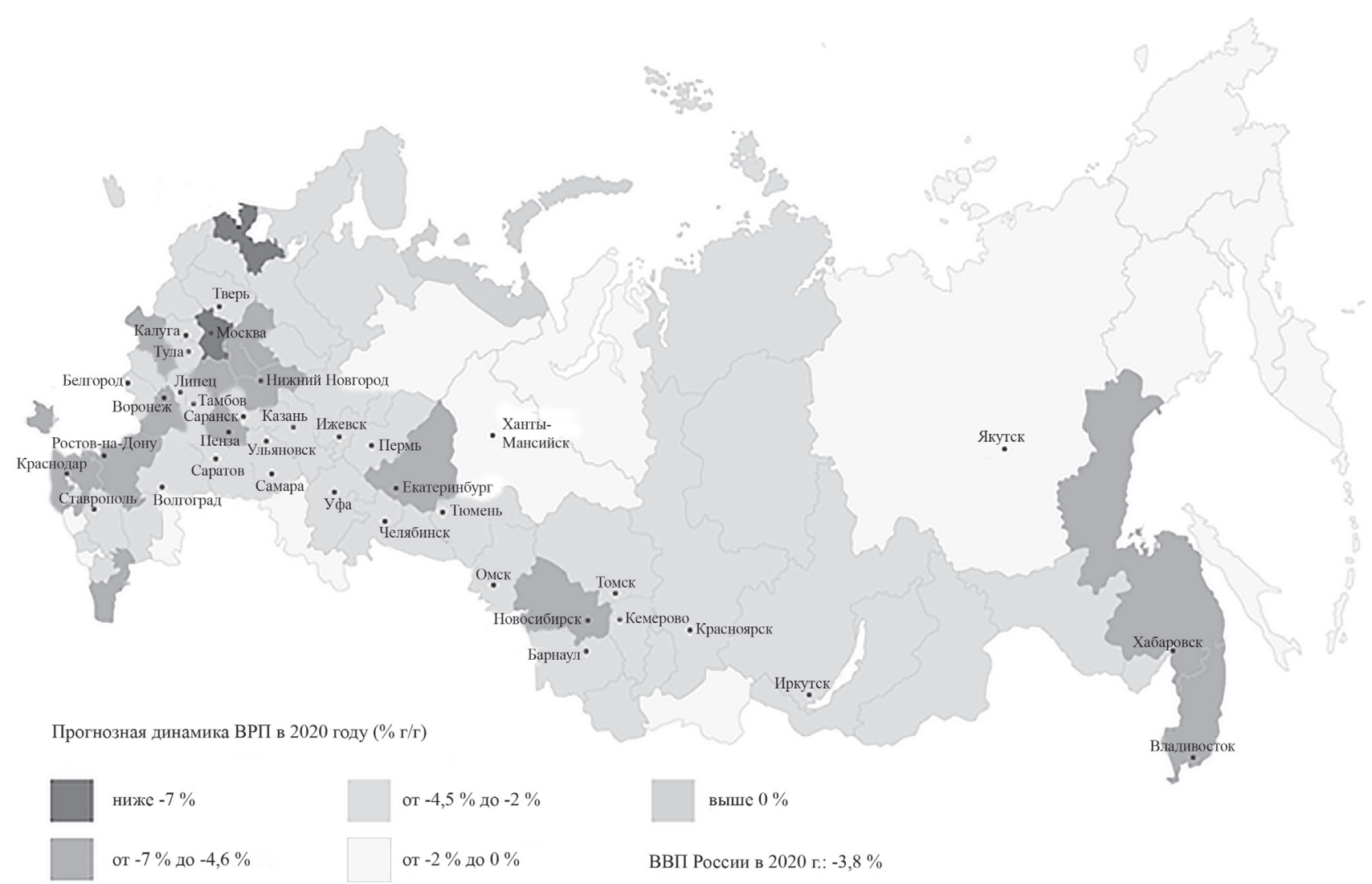

Источник: [16]

Рис. 2. Влияние пандемии коронавируса на состояние экономики отдельных регионов России

Регионы, наименее пострадавщие от коронавируса

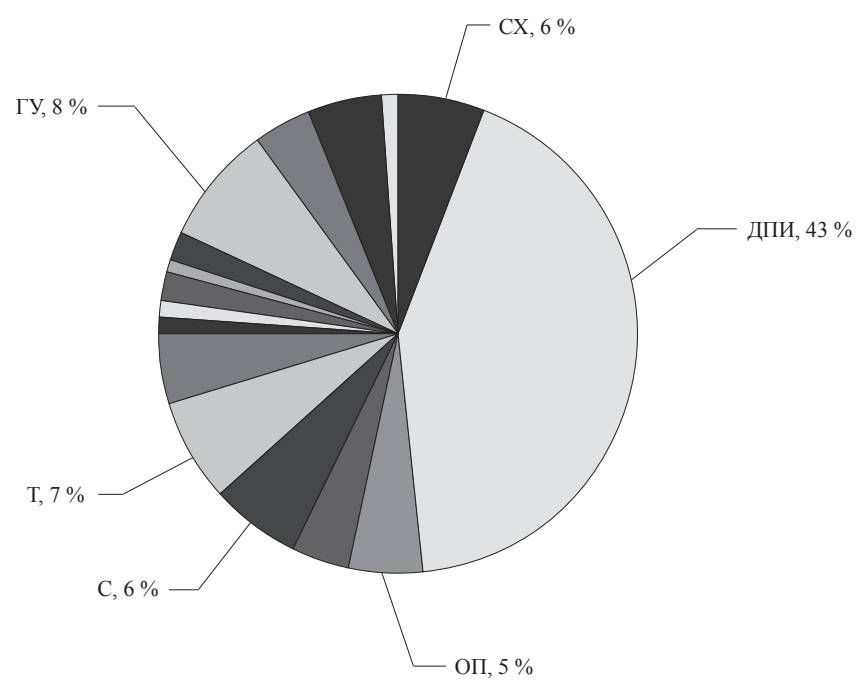

Регионы, наиболее пострадавщие от коронавируса

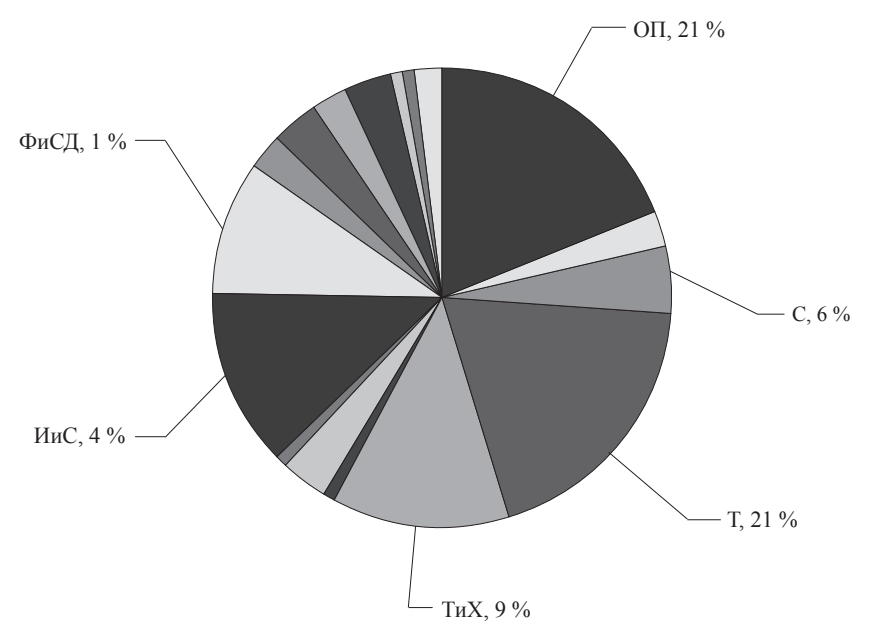

СХ - сельское хозяйство, ДПИ - добыча полезных ископаемых, ОП - обрабатывающие полезные ископаемые, С - строительство, $\mathrm{T}$ - торговля, ТиХ - транспортировка и хранение, ИиС - информация и связь, ФиСД - финансовая и страховая деятельность, ГУ государственное управление

Составлено авторами по материалам исследования

Рис. 3. Структура ВРП 2018 г. регионов, наименее и наиболее пострадавших от коронавируса по прогнозу ВЭБ.РФ 
В целом наиболее уязвимые сектора российской экономики по прогнозу снижения добавленной стоимости: гостиницы и общественное питание (-22,2 \% в 2020 г. по сравнению с 2019 г.), культура и спорт (-21,2\%), транспорт (-10,6\%) [17].

Вне зависимости от региона, экономические и социальные последствия распространения коронавируса нефтяного кризиса будут зависеть от предпринятых антикризисных мер в дополнение утвержденных Правительством Российской Федерации на данный момент.

Одним из регионов, в структуре которого значительную долю составляют обрабатывающие производства является Республика Башкортостан (по переработке и производству нефтепродуктов регион занимает 1 место в стране).

Современная структура экономики и социальной сферы Республики Башкортостан вызывает озабоченность с точки зрения устойчивости внешним кризисам по нескольким основаниям: относительно узкая специализация региона на обрабатывающей промышленности (35,1 \% ВРП региона в 2018 г.); недостаточное развитие малого и среднего бизнеса, быстрорастущих компаний (по обороту субъектов малого и среднего предпринимательства на душу населения Республика Башкортостан в 2019 г. занимает 40 место среди субъектов Российской Федерации), как следствие, ограниченное следование трендам формирования новых секторов экономики; неиспользование значительного сельскохозяйственного потенциала региона (несмотря на то, что большинство муниципальных районов региона являются сельскохозяйственными, доля сельского хозяйства в ВРП региона в 2018 г. не превышает 6,0 \%); недостаточная ориентированность на социальные нужды и потребности человека (доля расходов консолидированного бюджета РБ на здравоохранение за период 2012-2018 гг. снизилась с 18,9 \% до 8,8 \%, численность койко-мест на 10000 населения снижается ежегодно, это безусловно отразилось на готовности системы здравоохранения региона к пандемии).

Все это обусловливает необходимость проведения комплексных межотраслевых исследований последствий влияния пандемии на социально-экономическое развитие Республики Башкортостан и разработки антикризисных мер их преодоления. Ключевым здесь является изменение стратегического видения региона в сторону структурной и пространственной перестройки экономики региона. Не рассматривая в статье подробные направления развития, отметим ключевые моменты.

1. Структурная перестройка экономики Республики Башкортостан. Как уже было отмечено ранее, основу экономики региона составляет обрабатывающая промышленность, (35,1\% от ВРП в 2018 г.) прежде всего нефтяная (в структуре обрабатывающей промышленности 46,3% в 2018 г. приходится на производство кокса и нефтепродуктов; производство резиновых и пластмассовых изделий). По первичной переработке нефти в 2018 г. Республика Башкортостан заняла 2 место с долей в общероссийском объеме производства 8,6 \%, 1 место по производству дизельного топлива, бензола, 2 место по производству автомобильного бензина, этилена [16]. В Стратегии социально-экономического развития Республики Башкортостан до 2030 г. отмечается, что производство нефтепродуктов является конкурентным преимуществом Республики Башкортостан, компетенцией, которую объективно необходимо поддерживать [1].

В целом последствия коронавируса на развитие отрасли окажутся не столь существенными, в частности, согласно данным Министерства промышленности Республики Башкортостан, ограничения в связи с распространением коронавируса не могут повлиять на сбыт продукции предприятий газохимической и нефтехимической отрасли Республики Башкортостан [14].

Но нужно понимать, что объективно сформировались новые условия функционирования отрасли. Одной из угроз технологического развития обрабатывающей промышленности Республики Башкортостан является низкий уровень производительности труда и недостаточная доля высокопроизводительных рабочих мест. Однако текущие меры промышленной политики региона, в частности то, что Республика Башкортостан приступила к реализации мероприятий приоритетной программы «Повышение производительности труда и поддержка занятости» в конце 2017 г. в числе семи пилотных регионов России, привели к улучшению этих показателей. В 2018 г. по индексу производительности труда республика заняла 1 место среди регионов Приволжского федерального округа и 13 место среди регионов России со значением 104,6 \% (в 2017 г. - 8 и 22 место соответственно) [12; 15].

На сегодня необходимы дополнительные меры по цифровизации отрасли, создание условий для внедрения цифровых технологий и платформенных решений, обеспечение подготовки высококвалифицированных кадров для цифровой энергетики, цифровизация государственного управления и контрольно-надзорной деятельности в отраслях топливно-энергетического комплекса 
Прежде всего, это касается сельского хозяйства. По производству сельскохозяйственной продукции регион в 2018 г. занимает 7 место в стране. На сегодня доля сельского хозяйства в ВРП составляет 6,0 \%, однако вполне вероятно, что это доля в будущем снизится, даже несмотря на большой потенциал отрасли для региона. Так, согласно прогнозу Министерства экономического развития Республики Башкортостан рост показателя объема продукции сельского хозяйства в хозяйствах всех категорий к 2036 г. составит 2,5 раза (в текущих ценах) при общем росте ВРП за аналогичный период в 3,3 раза [2]. Простые сопоставления позволяют предположить, что доля сельского хозяйства в ВРП региона в 2036 г. снизится. Новые направления развития сельского хозяйства должны быть связаны как с новой волной импортозамещения, связанной с последствиями коронавируса, так и адаптацией отрасли республики к современным требованиям всеобщей цифровизации [11].

2. Разработка Стратегии пространственного развития региона. На первый взгляд меры по сбалансированному пространственному развитию региона к антикризисным мерам преодоления последствий коронавируса не относятся. Но это не так. Долгосрочная экономическая и социальная устойчивость региона определяется внутренним объективно формирующимся, но грамотно настраиваемым региональными властями экономическим каркасом территории, балансом «центр-периферийных» отношений. Это позволяет как развивать «точки роста», так и не допускать усиления разрывов в социально-экономическом развитии муниципальных образований региона.

Особенности пространственного развития Республики Башкортостан выражаются в том, на сегодня экономическое пространство Республики Башкортостан концентрируется в четырех агломерациях региона (прежде всего в Уфимской агломерации, а также в Южно-Башкортостанской, Нефтекамской и Октябрьск-Туймазинской). Остальная территория региона представляет собой периферийную территорию. Игнорировать этот факт уже трудно: 18 из 62 муниципалитетов (муниципальных районов и городских округов) республики концентрируют 90 \% объема отгруженной продукции, 84 \% инвестиций, 80 \% хозяйствующих субъектов Республики Башкортостан, в них сосредоточен 81 \% оборота розничной торговли, 70 \% вводимого жилья.

Однако в Стратегии социально-экономического развития Республики Башкортостан [1] говорится только о двух очевидных агломерациях: Уфимской и Южно-Башкортостанской, при этом указывается лишь в общих чертах необходимость их институционального оформления. Возможно две другие агломерации не являются классическими по всем общепринятым признакам, но их развитие принципиально важно для региона с точки зрения сбалансированного развития.

Даже независимые исследования сторонних авторов показывают, что, «по крайней мере, города Стерлитамак, Салават, Нефтекамск и Октябрьский, которые при соответствующем финансировании и размещении в них новых производств способны в целом сбалансировать территориальное размещение населения в Республике Башкортостан, приведя его в большее соответствие с законами Ципфа и Гибрата» [3].

Необходима Стратегия пространственного развития региона, которая бы учитывала неоднородность экономического развития муниципальных образований региона и определила направления развития текущих функциональных (субрегионы, зоны территориального развития и др.), каркасных (опорный каркас и ось развития, система расселения, транспортные узлы), кластерных (промышленные, туристские, инновационные) и административных (муниципалитеты) моделей пространственного развития Республики Башкортостан [5]. В частности, учитывая, что ландшафт расселения регионов Урала и Поволжья в результате современной политики регионального развития неизбежно ведет к усилению процессов сегрегации экономического пространства России [4].

В целом необходим пересмотр общего стратегического видения развития Республики Башкортостан в отраслевой и пространственной проекциях для обеспечения региональной экономической и социальной устойчивости внешним и внутренним угрозам развития.

Библиографический список

1. Постановление Правительства Республики Башкортостан от 20.12.2018 № 624 «О Стратегии социально-экономического развития Республики Башкортостан на период до 2030 года» // СПС «КонсультантПлюс» [Электронный ресурс]. - Режим доступа: http:// www.consultant.ru/regbase/cgi/online.cgi?req=doc;base=RLAW140;n=127734\#0041546090173500305 (дата обращения: 01.08.2020).

2. Распоряжение Правительства Республики Башкортостан от 15.01.2020 № 10-р «О прогнозе социально-экономического развития Республики Башкортостан на долгосрочный период до 2036 года» // Министерство экономической политики и инвестиционного развития Республики Башкортостан [Электронный ресурс]. - Режим доступа: https://economy.bashkortostan. ru/dejatelnost/makrojekonomika/prognoz-sotsialno-ekonomicheskogo-razvitiya/prognoz-ser-rb/ (дата обращения: 01.08.2020). 
3. Андреев, В. В., Лукиянова, В. Ю., Кадышев, Е. Н. Анализ территориального распределения населения в субъектах Приволжского федерального округа с применением законов Ципфа и Гибрата // Прикладная эконометрика. - 2017. - № 4 (48). - С. 97-121.

4. Гайнанов, Д. А., Шеломенцев, А. Г., Атаева, А. Г. Трансформация расселения на Урале и в Поволжье после реформы местного самоуправления // Социологические исследования. - 2017. - № 10 (402). - С. 64-76.

5. Гатауллин, Р. Ф., Каримов, А. Г., Уляева, А. Г. Некоторые аспекты диагностики структуры регионального экономического пространства // Фундаментальные исследования. - 2016. - № 4-2. - С. 374-380.

6. Григорьев, Л. М. Мировая социальная драма Пандемии и Рецессии // Население и экономика. - 2020. - Т. 4. - № 2. - С. 18-25.

7. Григорьев, Л. М., Павлюшина, В. А., Музыченко, Е. Э. Падение в мировую рецессию 2020 ... // Вопросы экономики. 2020. - № 5. - С. 5-24.

8. Колодко, Г. В. Последствия. Экономика и политика в постпандемическом мире // Вопросы экономики. - 2020. - № 5. - С. 25-44.

9. Банк России принял решение снизить ключевую ставку на 50 б.п., до 5,50 \% годовых // Банк России [Электронный ресурс]. - Режим доступа: http://cbr.ru/press/pr/?file=24042020_133000Key.htm (дата обращения: 01.08.2020).

10. Взаимная торговля стран БРИКС: Бюллетень о текущих тенденциях мировой экономики № 55 // Аналитический центр при Правительстве Российской Федерации [Электронный ресурс]. - Режим доступа: https://ac.gov.ru/uploads/2-Publicat ions $/ \% \mathrm{D} 0 \% \mathrm{~B} 0 \% \mathrm{D} 0 \% \mathrm{BF} \% \mathrm{D} 1 \% 80 \_2020 \_$web.pdf (дата обращения: 01.08.2020).

11. Давлетшин, И., Трофимов, А. Цифровой передел. Преимущества и риски цифровизации сельского хозяйства // Агроинвестор [Электронный ресурс]. - Режим доступа: https://www.agroinvestor.ru/technologies/article/30405-tsifrovoy-peredel/ (дата обращения: 01.08.20).

12. Индекс производительности труда // Федеральная служба государственной статистики Российской Федерации [Электронный pecypc]. - Режим доступа: https://www.gks.ru/folder/11186 (дата обращения: 01.08.2020).

13. Калюков, Е., Старостина, Ю. Силуанов назвал коронавирус угрозой сильнее падения цен на нефть // РБК [Электронный pecypc]. - Режим доступа: https://www.rbc.ru/economics/19/03/2020/5e7335ce9a7947a2864bc898 (дата обращения: 01.08.2020).

14. Кутлуева, А. В Башкирии оценили влияние коронавируса на разные отрасли экономики // РБК [Электронный ресурс]. Режим доступа: https://ufa.rbc.ru/ufa/12/03/2020/5e6a2af59a794712c38c7338 (дата обращения: 01.08.2020).

15. Производительность труда в Республике Башкортостан // Министерство экономической политики и инвестиционного развития Республики Башкортостан [Электронный ресурс]. - Режим доступа: https://economy.bashkortostan.ru/dejatelnost/ proektnyy-ofis/proizvoditelnost-truda/?PAGEN_1=4 (дата обращения: 01.08.2020).

16. Промышленность Республики Башкортостан: статистический сборник. - Уфа: Башкортостанстат, 2019. - 134 с.

17. Тенденции развития российской экономики в условиях пандемии коронавируса и возможные антикризисные меры // Институт исследований и экспертизы ВЭБ РФ [Электронный ресурс]. - Режим доступа: http://www.inveb.ru/ru/products/ product-02/247-tendentsii-razvitiya-rossijskoj-ekonomiki-v-usloviyakh-pandemii-koronavirusa-i-vozmozhnye-antikrizisnyemery (дата обращения: 01.08.2020).

18. Т Ткачёв, И., Старостина, Ю., Чернышова, Е. Экономисты допустили падение экономики России ниже уровня 2011 года // РБК [Электронный ресурс]. - Режим доступа: https://www.rbc.ru/economics/10/04/2020/5e8f108f9a794727b206ba88 (дата обращения: 01.08.2020).

\section{References}

1. Postanovlenie Pravitel'stva Respubliki Bashkortostan ot 20.12.2018 № 624 “O Strategii sotsial'no-ekonomicheskogo razvitiya Respubliki Bashkortostan na period do 2030 goda" [Resolution of the Government of the Republic of Bashkortostan "On the Strategy for the Socio-Economic Development of the Republic of Bashkortostan for the Period until 2030" No. 624, dated on December 20, 2018]. Legal reference system "ConsultantPlus". Available at: http://www.consultant.ru/regbase/cgi/online. cgi?req=doc;base=RLAW140; $\mathrm{n}=127734 \# 0041546090173500305$ (accessed 01.08.2020).

2. Rasporyazhenie Pravitel'stva Respubliki Bashkortostan ot 15 yanvarya 2020 goda №10-r “O prognoze sotsial'no-ekonomicheskogo razvitiya Respubliki Bashkortostan na dolgosrochnyi period do 2036 goda" [Order of the Government of the Republic of Bashkortostan "On the Forecast of the Socio-Economic Development of the Republic of Bashkortostan for the Long Term until 2036" No. 10-r, dated on January 15, 2020]. Ministerstvo ekonomicheskoi politiki i investitsionnogo razvitiya Respubliki Bashkortostan [Ministry of Economic Policy and Investment Development of the Republic of Bashkortostan]. Available at: https://economy. bashkortostan.ru/dejatelnost/makrojekonomika/prognoz-sotsialno-ekonomicheskogo-razvitiya/prognoz-ser-rb/(accessed 01.08.2020).

3. Andreev V.V., Lukiyanova V.Yu., Kadyshev E.N. Analiz territorial'nogo raspredeleniya naseleniya v sub"ektakh Privolzhskogo federal'nogo okruga s primeneniem zakonov Tsipfa i Gibrata [Analysis of the territorial distribution of the population in the subjects of the Volga Federal District using the laws of Zipf and Gibrat]. Prikladnaya ekonometrika [Applied Econometrics], 2017, no. 4 (48), pp. 97-121. 
4. Gainanov D.A., Shelomentsev A.G., Ataeva A.G. Transformatsiya rasseleniya na Urale i v Povolzh'e posle reformy mestnogo samoupravleniya [Transformation of settlement in the Urals and the Volga region after the reform of local government]. Sotsiologicheskie issledovaniya [Sociological Studies], 2017, no. 10 (402), pp. 64-76.

5. Gataullin R.F., Karimov A.G, Ulyaeva A.G. Nekotorye aspekty diagnostiki struktury regional'nogo ekonomicheskogo prostranstva [Some aspects of diagnostics of the structure of the regional economic space]. Fundamental'nye issledovaniya [Fundamental research], 2016, no. 4-2, pp. 374-380.

6. Grigor'ev L. M. Mirovaya sotsial'naya drama Pandemii i Retsessii [World social drama of the Pandemic and Recession]. Naselenie i ekonomika [Population and Economics], 2020, vol. 4, no. 2, pp. 18-25.

7. Grigor'ev L. M., Pavlyushina V. A., Muzychenko E. E. Padenie v mirovuyu retsessiyu 2020 [Fall in world recession 2020]. Voprosy ekonomiki, 2020, no.5, pp. 5-24.

8. Kolodko G. V. Posledstviya. Ekonomika i politika v postpandemicheskom mire [Consequences. Economics and politics in the post-pandemic world]. Voprosy Ekonomiki, 2020, no.5, pp. 25-44.

9. Bank Rossii prinyal reshenie snizit' klyuchevuyu stavku na 50 b.p., do $50 \%$ godovykh [Parameters of the base scenario of the forecast of the Bank of Russia were substantially revised]. Bank Rossii [Bank of Russia]. Available at: http://cbr.ru/press/pr/?file=24042020_133000Key.htm (accessed 01.08.2020).

10. Vzaimnaya torgovlya stran BRICS: Byulleten’ o tekushchikh tendentsiyakh mirovoi ekonomiki №55 [Mutual trade of the BRICS countries. The bulletin on current trends in the global economy. No. 55]. Analiticheskii tsentr pri Pravitel'stve Rossiyskoi Federatsii [Analytical Center for the Government of the Russian Federation]. Available at: https://ac.gov.ru/uploads/2-Publications $/ \% \mathrm{D} 0 \% \mathrm{~B} 0 \% \mathrm{D} 0 \% \mathrm{BF} \% \mathrm{D} 1 \% 80 \_2020 \_$web.pdf (accessed 01.08.2020).

11. Davletshin I., Trofimov A. Tsifrovoi peredel. Preimushchestva i riski tsifrovizatsii sel'skogo khozyaistva [Digital redistribution. Benefits and risks of agricultural digitalization]. Agroinvestor. Available at: https://www.agroinvestor.ru/technologies/ article/30405-tsifrovoy-peredel/ (accessed 01.08.2020).

12. Indeks proizvoditel'nosti truda [Labor productivity index]. Federal'naya sluzhba gosudarstvennoi statistiki Rossiiskoi Federatsii [Federal State Statistic Service of the Russian Federation]. Available at: https://www.gks.ru/folder/11186 (accessed 01.08.2020).

13. Kalyukov E., Starostina Yu. Siluanov nazval koronavirus ugrozoi sil'nee padeniya tsen na neft' [Siluanov called coronavirus a threat stronger than falling oil prices]. RBK [RBC]. Available at: https://www.rbc.ru/economics/19/03/2020/5e7335ce9a794 7a2864bc898_(accessed 01.08.2020).

14. Kutlueva A. V Bashkirii otsenili vliyaniy koronavirusa na raznye otrasli ekonomiki [In Bashkiria the impact of coronavirus on various sectors of the economy was assessed]. RBK $[R B C]$. Available at: https://ufa.rbc.ru/ufa/12/03/2020/5e6a2af59a794712c38c7338_(accessed 01.08.2020).

15. Proizvoditel'nost' truda v Respublike Bashkortostan [Labor productivity in the Republic of Bashkortostan]. Ministerstvo ekonomicheskoi politiki i investitsionnogo razvitiya Respubliki Bashkortostan [Ministry of Economic Policy and Investment Development of the Republic of Bashkortostan]. Available at: https://economy.bashkortostan.ru/dejatelnost/proektnyy-ofis/proizvoditelnost-truda/?PAGEN_1=4 (accessed 01.08.2020).

16. Promyshlennost' Respubliki Bashkortostan: statisticheskii sbornik [Industry of the Republic of Bashkortostan: statistical compilation]. Ufa, Bashkortostanstat, 2019. 134 p.

17. Tendentsii razvitiya rossiyskoi ekonomiki v usloviyakh pandemii koronavirusa i vozmozhnye antikrizisnye mery [Development trends of the Russian economy in the context of the coronavirus pandemic and possible anti-crisis measures]. Institut issledovanii i ekspertizy VEB RF [Vnesheconombank Institute]. Available at: http://www.inveb.ru/_(accessed 01.08.2020).

18. Tkachev I., Starostina Yu., Chernysheva E. Ekonomisty dopustili padenie ekonomiki Rossii nizhe urovnya 2011 goda [Economists allowed the Russian economy to fall below the 2011 level]. RBK [RBC]. Available at: https://www.rbc.ru/economics/10/04/2020/5e8f108f9a794727b206ba88_(accessed 01.08.2020). 